\title{
Communication
}

[Comunicação]

\section{Occurrence of antibodies anti-Neospora spp. in cart horses and Crioula breed horses from Rio Grande do Sul State}

\author{
[Ocorrência de anticorpos anti-Neospora spp. em cavalos de carroça e equinos da raça Crioula \\ no estado do Rio Grande do Sul] \\ G. Toscan $^{1}$, F.S.F. Vogel $^{1}$, G.C. Cadore ${ }^{1}$, A.S. Cezar ${ }^{1}$, L.A. Sangioni ${ }^{1}$, R.C.F. Pereira ${ }^{2}$ \\ L.S.S. Oliveira ${ }^{2}$, S.T.A. Lopes $^{2}$ \\ ${ }^{1}$ Universidade Federal de Santa Maria - UFSM \\ 97105-900 - Santa Maria, RS \\ ${ }^{2}$ Hospital Veterinário - UFSM - Santa Maria, RS
}

The protozoa of the genus Neospora spp. (Apicomplexa, Sarcocystidae) are capable of infecting equines causing different clinical manifestations. However, the pathogenesis of these protozoa in horses has not been fully explained yet. Two species of the genus Neospora spp. have already been described parasitizing equines - Neospora caninum and Neospora hughesi. The infection by $N$. caninum is mainly characterized by reproductive problems and neonatal illness, and $N$. hughesi is associated with myeloencephalitis (Dubey and Porterfield, 1990; Lindsay, 2001).

$N$. caninum was firstly described in dogs in Norway (Bjerkas et al., 1984), from there on, it has been described in many warm-blooded species (Dubey and Lindsay, 1996). N. hughesi has been reported for the first time by Marsh et al. (1998) who isolated a protozoan very similar to $N$. caninum (however, with structural and molecular differences) from brain and spinal marrow of a horse that was showing signs compatible with equine protozoal myeloencephalitis (EPM).

The biological cycle of $N$. caninum was described by McAllister et al. (1998) and involves definitive (DH) and intermediate (IH) hosts. The definitive ones are dogs and coyotes (McAllister et al., 1998; Gondim et al., 2004) and, besides sheltering the agent, they are characterized by excreting oocysts in their feces. These oocysts sporulate in the environment becoming infective for the IH, group in which fit several mammalian species (Dubey and Lindsay, 1996).

$N$. caninum can disseminate itself in susceptible populations by the horizontal route (sporulated oocysts), and by the vertical transmission via placenta (by tachyzoites). In the stage of tachyzoite, the protozoan is able to accomplish parasitaemia and new cells invasion. The infected IH develop cysts containing bradyzoites (slow multiplication form), and the DH are infected by eating tissues containing these cysts (Dubey et al., 2007).

The biological cycle of $N$. hughesi was not entirely elucidated until the moment; its definitive host is unknown, as well as other possible intermediate hosts besides equines. Consequently, the infection routes for $N$. hughesi in horses are not determined (Hoane et al., 2006). The discovery of $N$. hughesi as a possible etiological agent of EPM turned out to be of great importance in its diagnosis, since Neospora spp. has been reported in cases of this pathology (Marsh et al., 1998). However, it is still undefined if both protozoan species are able to cause this kind of myeloencephalitis. 
In Brazil, studies concerning prevalence of Neospora spp. in equines are rare, with detection indexes ranging from 2.5\% (Hoane et al., 2006) to $47 \%$ (Locatelli-Dittrich et al., 2006). Besides, Dubey et al. (1999a) tested serum samples of 101 Brazilian horses and found no antibodies antiNeospora spp. The aim of the present study was to evaluate the frequency of antibodies antiNeospora spp. and to compare the occurrence of these antibodies in cart horses and Crioula breed horses, all from central region of Rio Grande do Sul State.

Serum samples were obtained from 241 horses aging from four to 14 years old, being 91 from cart horses and the other 123 from Crioula breed horses. The blood samples were collected from jugular vein in vacutainer tubes. After the retraction of the clot, the serum was collected and kept under low temperature or frozen until processing. The cart horses were used to carry loads and most of them had no defined breed and Crioula breed horses were from stud farms. Only animals that were in a strictly characteristic epidemiological situation were included in each group.

The search for antibodies anti-Neospora spp. was made using indirect fluorescent antibody test (IFAT). The IFAT was performed on microscope slides containing tachyzoites of NC-1 strain, fixed with methanol. Serum samples were diluted into PBS (1:50) and used as primary antibody (incubated at $37^{\circ} \mathrm{C}$ for $30 \mathrm{~min}$ in a humid chamber). As secondary antibody, equine anti-IgG $^{\oplus 1}$ conjugate to fluorescein (diluted to 1:75 and incubated as previously described) was utilized. The slides were analyzed using an epifluorescent microscope and samples that showed peripheral or difuse fluorescence were considered positive.

The statistical analysis of the data was done by the Tukey test with significance level of 5\%. This test was performed using the SAS/1996 software.

The frequency of antibodies against Neospora spp., including both populations, was $15.9 \%$ (34/214). The frequency of positive serology in the cart horses was $15.4 \%$ (14/91) and in Crioula breed was $16.3 \%$ (20/123). There was no significant difference in antibodies frequency between the analyzed groups of horses.
The frequency of antibodies anti-Neospora spp. was high. Dubey et al. (1999a,b) did not detect antibodies anti-Neospora spp. in horses neither from Brazil (0/101) nor from Argentina (0/76). Hoane et al. (2006) found a prevalence of $2.5 \%$ (24/961) in equine serum samples from different regions of Brazil, although the prevalence was 3.5\% (5/172) in the States of Rio Grande do Sul, Santa Catarina, and Paraná. Villalobos et al. (2006) detected a frequency of 10.3\% (114/1106) for antibodies anti-Neospora spp. in horses in the State of São Paulo. Also, in mares with history of reproductive problems, as abortion on the third gestational trimester or neonatal mortality, the percentage of positive animals increased to $15.1 \%(73 / 483)$.

In the United States, Cheadle et al. (1999) and McDole and Gay (2002) found, respectively, $11.5 \%$ and $10 \%$ of seropositive horses for Neospora spp.. However, in other studies, the indexes of antibodies detection were higher. Dubey et al. (1999c) noticed 23.3\% of seropositivity in equines in an abattoir in the USA. In Italy, Ciaramella et al. (2004) found a prevalence of $28 \%(42 / 150)$.

In the present study, it was not taken into account neither the report of possible reproductive problems nor the occurrence of EPM. Probably, the highest indexes of anti-Neospora spp. antibodies should be found in serum samples from animals and/or from farms with a history of reproductive or neurological diseases. Anyway, the results found here show that these protozoa are present in a relevant form in both populations of horses.

The similar frequency of seropositivity found in cart horses and Crioula breed horses could be due the two routes of infection by Neospora spp.: vertical (transplacental) and horizontal (ingestion of sporulated oocysts) transmissions. However, it is well known that the epidemiological aspects concerning both studied populations are totally different. Due to the open character of the population of cart horses (because of large mobility) a major infection source to these animals, probably, is the intake of sporulated oocysts present in the environment after the excretion by $\mathrm{DH}$. Additionaly, it should be considered that some of these horses may have been infected by vertical route. In Crioula breed horses, which belong to a controlled population 
(with restricted mobility), it is presumable that both infection forms may have similar importance.

Other studies concerning the infection routes of $N$. caninum and $N$. hughesi in horses are necessary. Furthermore, it should be noted that, due to the pattern of the pathogenesis of these protozoa in equines, neosporosis should be included in the diagnosis of reproductive problems in mares and in cases of EPM. The protozoa of the genus Neospora spp. are present in the studied equine populations. Further studies need to be performed with the aim of defining the matter related to transplacental passage of these protozoa in horses.

Keywords: horse, Neospora caninum, Neospora hughesi, IFAT

\section{RESUMO}

O objetivo deste estudo foi avaliar a frequência de detecção de anticorpos contra Neospora spp. em cavalos de carroça e em cavalos da raça Crioula. Para tal, 214 amostras de soro foram coletadas e analisadas pela técnica de imunofluorescência indireta, das quais 91 eram de cavalos de carroça e 123 de cavalos da raça Crioula, todas provenientes da região central do Rio Grande do Sul. As frequências de anticorpos detectadas foram: 15,9\% (34/214) na população total estudada, 15,4\% (14/91) nos cavalos de carroça e 16,3\% (20/123) nos cavalos da raça Crioula. Estes resultados sugerem que a infecção por Neospora spp. está presente igualmente nas duas populações. Assim, devido à importância e ao padrão da patogênese da neosporose em equinos, Neospora spp. deve ser incluído no diagnóstico de problemas reprodutivos em éguas e em casos de problemas neurológicos em equinos.

Palavras-chave: equino, Neospora caninum, Neospora hughesi, RIFI

\section{ACKNOWLEDGEMENTS}

We are thanked to Professors Rudi Weiblen and Eduardo Furtado Flores to make available the Laboratory of Virology at the UFSM for the accomplishment of this study.

\section{REFERENCES}

BJERKAS, I.; MOHN, S.F.; PRESTHUS, J. Unidentified cyst-forming Sporozoon causing encephalomyelitis and myositis in dogs. Z. Parasitenkd., v.70, p.271-274, 1984.

CHEADLE, M.A.; LINDSAY, D.S.; ROWE, S. et al. Prevalence of antibodies to Neospora sp. in horses from Alabama and characterization of an isolate recovered from a naturally infected horse. Int. J. Parasitol., v.29, p.1537-1543, 1999.

CIARAMELLA, P.; CORONA, M.; CORTESE, L. et al. Seroprevalence of Neospora spp. in asymptomatic horses in Italy. Vet. Parasitol., v.123, p.11-15, 2004.

DUBEY, J.P.; LINDSAY, D.S. A review of Neospora caninum and neosporosis. Vet. Parasitol., v.67, p.1-59, 1996.
DUBEY, J.P.; PORTERFIELD, M.L. Neospora caninum (Apicomplexa) in an aborted equine fetus. J. Parasitol., v.76, p.732-734, 1990.

DUBEY, J.P.; KERBER, C.E.; GRANSTRON, D.E. Serologic prevalence of Sarcocystis neurona, Toxoplasma gondii, and Neospora caninum in horses in Brazil. J. Am. Vet. Med. Assoc., v.215, p.970-972, 1999a.

DUBEY, J.P.; VENTURINI, M.C.; VENTURINI, L. et al. Prevalence of antibodies to Sarcocystis neurona, Toxoplasma gondii, and Neospora caninum in horses from Argentina. Vet. Parasitol., v.86, p.59-62, 1999b.

DUBEY, J.P.; ROMAND, S.; THULLIEZ, P. et al. Prevalence of antibodies to Neospora caninum in horses in North America. J. Parasitol., v.85, p.968-969, 1999c.

DUBEY, J.P.; SCHARES, G.; ORTEGAMORA, L.M. Epidemiology and control of neosporosis and Neospora caninum. Clin. Microbiol. Rev., v.20, p.323-367, 2007.

GONDIM, L.F.P.; McALLISTER, M.M.; PITT, W.C. et al. Coyotes (Canis latrans) are definitive hosts of Neospora caninum. Int. J. Parasitol., v.34, p.159-161, 2004. 
HOANE, J.S.; GENNARI, S.M.; DUBEY, J.P. et al. Prevalence of Sarcocystis neurona and Neospora spp. infection in horses from Brazil based on presence of serum antibodies to parasite surface antigen. Vet. Parasitol., v.136, p.155159, 2006.

LINDSAY, D.S. Neosporosis: an emerging protozoal disease of horses. Equine Vet. J., v.33, p.116-118, 2001.

LOCATELLI-DITTRICH, R.; DITTRICH, J.R.; RICHARTZ, R.R.T.B. et al. Investigation of Neospora spp. and Toxoplasma gondii antibodies in mares and in precolostral foals from Paraná state, Southern Brazil. Vet. Parasitol., v.135, p.215-221, 2006.

MARSH, A.E.; BARR, B.C.; PACKHAM, A.E. et al. Description of a new Neospora species (Protozoa: Apicomplexa: Sarcocystidae). $J$. Parasitol., v.84, p.983-991, 1998.
McALLISTER, M.M.; DUBEY, J.P.; LINDSAY, D.S. et al. Dogs are definitive hosts of Neospora caninum. Int. J. Parasitol., v.28, p.1473-1478, 1998.

McDOLE, M.G.; GAY, J.M. Seroprevalence of antibodies against Neospora caninum in diagnostic equine serum samples and their possible association with fetal loss. Vet. Parasitol., v.105, p.257-260, 2002.

VILLALOBOS, E.M.C.; UENO, T.E.H.; SOUZA, S.L.P. et al. Association between the presence of serum antibodies against Neospora spp. and fetal loss in equines. Vet. Parasitol., v.142, p.372-375, 2006. 